\title{
Secondary Organic Compounds in Atmospheric Aerosols: Speciation and Formation Mechanisms
}

\author{
Célia A. Alves ${ }^{*, a}$ and Casimiro A. Pio ${ }^{b}$ \\ ${ }^{a}$ Escola Superior de Tecnologia e Gestão, Instituto Politécnico de Viana do Castelo, Av. do Atlântico, Apart. 574, \\ 4900-348 Viana do Castelo, Portugal \\ ${ }^{b}$ Departamento de Ambiente e Ordenamento, Universidade de Aveiro, 3800-193 \\ Aveiro, Portugal
}

\begin{abstract}
Atendendo às características fotoquímicas atmosféricas, as áreas florestadas dos países mediterrânicos constituem um ambiente apropriado para investigar os aerossóis orgânicos secundários. Este estudo visa estudar in situ a composição dos aerossóis, em particular os produtos resultantes da foto-oxidação de compostos orgânicos voláteis biogênicos, considerando simultaneamente a contribuição antropogênica, e explicar como estes compostos surgem nos aerossóis. As amostragens de matéria particulada atmosférica ocorreram em dois locais: uma floresta de Abies boressi na Grécia central e numa localidade rural próxima da costa, no centro de Portugal. A matéria orgânica presente nos aerossóis foi extraída com solventes e analisada por cromatografia gasosa e espectrometria de massa. Detectaram-se vários produtos resultantes da foto-oxidação de compostos orgânicos voláteis emitidos pela vegetação ou de precursores antropogênicos. Estes constituintes secundários incluem derivados de alcenos, ácidos oxo-, di- e monocarboxílicos, compostos aromáticos oxigenados, azaarenos, tio-arenos e muitos produtos da foto-oxidação dos terpenos. Esta experiência in situ possibilitou a confirmação da presença de constituintes secundários, os quais haviam sido estudados quase exclusivamente em atmosferas simuladas através de ensaios laboratoriais. Alguns mecanismos reacionais que explicam a formação de compostos na fase particulada a partir de precursores são aqui apresentados.
\end{abstract}

Taking into account their atmospheric characteristics, generally under photochemical conditions, forested areas of Mediterranean countries constitute an appropriate environment to investigate the secondary organic aerosols. The objective of this study was to study in situ the aerosol composition, particularly in the photo-oxidation products of biogenic volatile organic compounds, taking into consideration anthropogenic inputs, and to explain how these compounds appear in the aerosols. Atmospheric particulate matter was collected at two sites: an Abies boressi forest in central Greece and at Giesta, a coastal-rural site in the centre of Portugal. The collected aerosol was extracted with solvents and characterised by gas chromatography and mass spectrometry. The detected secondary organics include alkene derivatives, oxo-, di- and monocarboxylic acids, oxy-aromatics, aza and thia arenes, and many terpene photo-oxidation products. This in situ experiment allowed confirming the presence of secondary constituents, which have been studied almost exclusively under simulated laboratory conditions. Some reaction pathways leading to the formation of compounds in the particulate phase from precursors are presented.

Keywords: secondary organic aerosol, terpene oxidation, reaction mechanisms

\section{Introduction}

Organic compounds are important atmospheric components. The formation of organic aerosols represents one of the removal processes of volatile organic compounds (VOC). Thus, organic compounds play an important role in photochemical reactions leading to ozone formation. ${ }^{1}$ On the other hand, they compete with inorganic

\footnotetext{
* e-mail: celia@estg.ipvc.pt
}

compounds for oxidising species such as ozone, hydroxyl and nitrate radicals. ${ }^{2}$ If organic aerosols occur in the submicron range they can originate cloud condensation nuclei. ${ }^{3}$ Organic aerosols have been associated with indirect climate forcing, because they have optical properties and contribute to visibility degradation. ${ }^{4}$ Organic aerosols may change chemical, optical and hygroscopic properties of inorganic aerosols. ${ }^{5}$ The presence of some components (e.g. polyaromatic hydrocarbons) is a cause of concern since they have proven carcinogenic 
and/or mutagenic properties. ${ }^{6-8}$ A large fraction of organics is associated with particles smaller than $3 \mathrm{~mm}$, which can reach the respiratory system. ${ }^{9}$

Secondary organic aerosols (SOA) are formed from both biogenic and anthropogenic gaseous precursors. The major biogenic compounds involved in aerosol formation are considered to be monoterpenes, which constitute more than $80 \%$ of the VOC emissions from conifers. ${ }^{9}$ Approximately $50 \%$ of anthropogenic VOC are emitted by mobile sources, while industrial sources represent the second greatest VOC emitter. ${ }^{2}$ The formation of SOA can follow complex chemical pathways, many of which remain unknown. Despite the uncertainties, it is recognised that organic aerosol formation is typically dominated by $\mathrm{C}_{5}-\mathrm{C}_{10}$ species, because compounds with more than 10 carbons tend to be present at low concentration and species with small molecular weights have high saturation vapour pressures. ${ }^{2}$ Organic species can form new aerosols by condensation or react heterogeneously on pre-existing aerosols. ${ }^{10}$ Even when products are present at less than their saturation vapour pressure, they may still condense onto existing aerosols..$^{11,12}$

Species such as the hydroxyl radicals and ozone are expected to be atmospheric oxidants of hydrocarbons leading to products containing carbonyl $(-\mathrm{C}=\mathrm{O})$, carboxy $(-\mathrm{COOH})$, and hydroxy $(-\mathrm{OH})$ functional groups. $\mathrm{OH}$ radicals attack alkanes $\geq \mathrm{C}_{4}$ initiating their oxidation. Alkoxy radical intermediates are formed, which through isomerisation leads to the formation of carbonyl products. For hydrocarbons containing double bonds (e.g. alkenes) hydroxyl radical or ozone can start oxidation. The next reactions form products such as carbonyls, hydroxy carbonyls, dicarbonyls, carboxylic acids, and oxocarboxylic acids. ${ }^{13,14}$ The atmospheric residence time of non-methane hydrocarbons (NMHC) is determined by the $\mathrm{OH}$-radical concentration and for the unsaturated hydrocarbons, to a lesser extent, also by the ozone concentration. ${ }^{15}$

A detailed understanding of SOA formation in the atmosphere is essential to characterise the chemical composition of ambient organic aerosols, to accurately incorporate such processes in air quality models, and to be able to attribute the ambient organic aerosol mass to the appropriate man-made and natural sources. While aromatic hydrocarbons and biogenic terpenes are undoubtedly major contributors to SOA in the atmosphere, these two compound classes are not solely responsible for SOA formation. Currently, in fact, other potentially important contributors to SOA formation are only a matter of conjecture. In addition, there is a large amount of semivolatile organic material (direct emissions and photochemical oxidation products of VOC emissions) that has the potential to move into the particulate phase as climate or atmospheric chemistry undergoes subtle changes. ${ }^{16}$ The mass of such material is so large in comparison to amounts of material currently in the aerosol phase that impacts on $\mathrm{PM}_{2.5}$ are potentially significant. Thus, it is important to identify all such SOA precursors, their aerosol-forming potential, and their sources. ${ }^{16}$ The direct emission of organic matter to the atmosphere (primary organic aerosol) is relatively well characterised. On the contrary, the in situ formation of SOA by condensation of low volatility products of the photo oxidation of hydrocarbons remains poorly understood. ${ }^{17,18}$ Till now, SOA constituents have been studied almost exclusively in smog chamber experiments, under controlled conditions. ${ }^{19}$

Forest and semi-rural areas constitute an adequate environment for the study of the aerosol formation from the oxidation of natural hydrocarbons, taking simultaneously into consideration the anthropogenic influence during transport of air masses from urban areas. The objective of this work is to investigate in situ the formation of aerosol particles from biogenic volatile organic carbon, by a detailed study of aerosol composition, with focus on the photo oxidation products of biogenic VOC, compounds of higher molecular weight directly emitted by vegetation and contaminants derived from anthropogenic activity.

\section{Experimental}

Total suspended particulate matter (TSP) 6 hours samples were collected by filtering air through quartz fibre filters using high-volume samplers with a flow of $1.13 \mathrm{~m}^{3} \mathrm{~min}^{-1}$. One of the sampling sites was at Giesta (lat. 40³8'N; long. 8³9' W), a Portuguese rural site located in a large agricultural area, near a small village, surrounded by forest patches of pine and eucalyptus. Sources of anthropogenic and biogenic emissions within a $20 \mathrm{~km}$ radius include the coastal city of Aveiro and other smaller towns, national roads such as the North Motorway, forests, crops (especially maize) and the Pateira de Fermentelos lagoon. On summer days, during sea breezes, air masses originate in the Atlantic Ocean and are transported to the interior, taking approximately $1 \mathrm{~h}$ to travel between Aveiro and Giesta. ${ }^{20}$ Therefore, particulate matter collected at Giesta may reflect the composition of air masses, which are influenced by urban and rural emissions. Sample collection was done from August 1 to August 2, 1997. Another sampling campaign was done during the period from August 12 to August 25, 1997, in Pertouli (lat.: 39³0' N; long.: 21²5'W), Greece. The site was located at $1180 \mathrm{~m}$ of altitude in the Agrafa 
Mountains and near a small village of 60 inhabitants. The nearest city is Trikala, situated $45 \mathrm{~km}$ from the experimental site. The forest is constituted mainly by Abies boresii regis, representing $92 \%$ of the arboreous area around Pertouli (2550 ha). Other minimal vegetation like Pinus nigra and Pinus silvestris complete the remainder $8 \%$. Following sampling, the filters were frozen until laboratory analyses were initiated. Air masses originated from Continental Europe, hence concentrations of transported long-lived anthropogenic pollutants would be expected to be non-negligible. ${ }^{21}$

The methodology for the extraction of organic compounds in the atmospheric particulate matter was adapted from Stephanou and Stratigakis ${ }^{22}$ and Gogou et $a l .{ }^{23}$ All solvents were purchased from Merck ("Suprasolv" grade). Hundreds of authentic standards were obtained from Sigma-Aldrich for the positive identification and quantification of the organic compounds. Silica gel (0.040-0.063 $\mathrm{mm}$ ) was also from Merck. All materials used (silica gel, glass and cotton wool, paper filters, anhydrous sodium sulphate, etc.) were Soxhlet extracted with methanolacetone (50:50) overnight and twice with dichloromethane for $24 \mathrm{~h}$, and kept dry (in desiccator) until use. Quartz fibre filters were cleaned at $550{ }^{\circ} \mathrm{C}$ overnight. All glassware was cleaned by heating at $550{ }^{\circ} \mathrm{C}$, and rinsed with the applied organic solvent just before use.

Each sampled filter was cut into small pieces and its organic content extracted in a flask by refluxing dichloromethane for $24 \mathrm{~h}$. The extract was filtrated and the solvent concentrated to volumes of approximately 4 $\mathrm{mL}$. The resulting solvent extract was transferred to vials, evaporated until dryness using a stream of nitrogen. In order to separate individual classes of organic compounds, the vials were successively washed using 5 solvents of increasing polarity and transferred to the top of a $30 \times 0.7$ $\mathrm{cm}$ column containing $1.5 \mathrm{~g}$ of silica gel (activated at 150 ${ }^{\circ} \mathrm{C}$ for $3 \mathrm{~h}$ ), to fractionate the total organic extract by flash chromatography. Nitrogen pressure was used in order to obtain a flow of $1.4 \mathrm{~mL} \mathrm{~min}^{-1}$ at the bottom of the column. The following solvents were used to elute the different compound classes: (1) $15 \mathrm{~mL} n$-hexane (fraction 1 , aliphatics); (2) $15 \mathrm{~mL}$ toluene- $n$-hexane (5.6:9.4) [fraction 2 , polycyclic aromatic hydrocarbons $(\mathrm{PAH})$ and nitro-PAH]; (3) $15 \mathrm{~mL} n$-hexane-dichloromethane (7.5:7.5) (fraction 3, carbonyl compounds and oxy-PAH); (4) $20 \mathrm{~mL}$ ethyl acetate- $n$-hexane (8:12) (fraction $4, n$-alkanols, sterols and other hydroxyl compounds); and (5) $20 \mathrm{~mL}$ solution of pure formic acid in methanol (4\%, v/v) (fraction 5, acids). After each elution, the different fractions were vacuum concentrated (25-30 ${ }^{\circ} \mathrm{C}$ under reduced pressure) and evaporated by a gentle ultra pure nitrogen stream. The last two eluted fractions were derivatised using silylating and methylating reagents, respectively, from Supelco prior to analyses by gas chromatography-mass spectrometry (GCMS). The individual fractions were spiked with internal standards (1-chlorohexadecane for aliphatics, carbonyls, hydroxyl silyl ethers and for acid methyl esters; cholestane for sterol silyl ethers, and hexamethylbenzene for $\mathrm{PAH}$ ) for quantitative determinations.

The resulting five organic classes were analysed by a Hewlett Packard 6890 gas chromatograph equipped with a mass detector model 7873 and a 25 m HP-MS capillary column (0.25 mm i.d., $0.25 \mathrm{~mm}$ film thickness). Data were acquired in the electron impact (EI) mode (70 eV), scanning from 50 to 750 mass units at $1 \mathrm{~s}$ per decade. The oven temperature program was as follows: $60{ }^{\circ} \mathrm{C}(1 \mathrm{~min})$; 60$150{ }^{\circ} \mathrm{C}\left(10^{\circ} \mathrm{C} \min ^{-1}\right), 150-290{ }^{\circ} \mathrm{C}\left(5^{\circ} \mathrm{C} \mathrm{min}^{-1}\right), 290{ }^{\circ} \mathrm{C}(30$ min) and using Helium as carrier gas at $1.2 \mathrm{~mL} \mathrm{~min}^{-1}$. The mass scanning ranged between $\mathrm{m} / \mathrm{z}, 50$ and 500. Compound identification was based on the GC-MS spectra library and on co-injection with authentic standards. Compounds within the homologous series for which standards were not available were identified by comparing their spectra to the standards for similar compounds within the series and by comparison to the Wiley mass spectral library. Relative response factors were calculated for 3-10 standard compounds, representing each compound class, of increasing molecular mass. Relative response factors for monoterpene oxidation products were calculated for each single compound individually.

Recovery tests were carried out by spiking quartz fibre filters with a standard mixture of compounds, about $10 \mathrm{ng}$ each, which corresponds to an air concentration of $4 \mathrm{pg} \mathrm{m}^{-3}$. All the extraction, derivatisation and quantification procedure was repeated. The amount of each recovered standard was determined with an internal standard. The results were calculated from the previously determined relative response factors. The mean recoveries ranged from 82 to $107 \%$, depending on the analyte. The recoveries of monoterpene photo oxidation products were $98 \%$ for nopinone, $96 \%$ for pinonic acid and $95 \%$ for pinonaldehyde. Accuracy determinations were performed for both polar and nonpolar standard compounds, showing that the relative standard deviation within a group of similar compounds was between 2 and $8 \%$, depending on the amount of standard compound injected. Control of procedural blanks has been performed to assess possible contamination. The total blank weight never exceeded $2 \%$ of the individual sample extracts, except for the acid fraction, where the maximum contamination represented $8 \%$ of the total fraction extract. The most frequent contaminants were 
phthalate esters, which did not interfere with quantification of compounds of interest. All quantities given here were corrected, taking into consideration the application of the analytical methodology with standard compounds (column chromatography performance and relative response factors in GC-MS). Limits of detection for individual compounds (typically $0.02-0.08 \mathrm{pg} \mathrm{m}^{-3}$, depending on the analyte) were defined as the mean blank mass plus three standard deviations.

\section{Results and Discussion}

A number of studies have shown that the PAH emissions from motor vehicles increase with increasing aromatic hydrocarbon content of fuel. It has been reported that $95 \%$ of the PAH present in the exhaust are combustion-derived, rather than originated from unburned fuel. ${ }^{6}$ Aromatic hydrocarbons form PAH by dimerisation followed by condensation. PAH are detected in the aerosol phase adsorbed onto particulate matter. ${ }^{6}$ Higher PAH levels should be found in winter since photochemical degradation due to sun irradiation occurs in summer, thus lowering the PAH concentration. ${ }^{15,24}$ Particularly, the photochemical reaction of PAH with ozone is noted as a factor contributing to the removal of PAH from the atmosphere. ${ }^{6}$ Previous studies have already shown that higher PAH concentrations are observed in winter as a consequence of an increase in consumption of fossil fuel combustibles, lower losses due to photochemical degradation and the fact that meteorological conditions during this period (i.e. more frequent and lower temperature inversions) are less favourable for pollutant dispersion. ${ }^{25} \mathrm{Oxy}-\mathrm{PAH}$ and quinones are formed by oxidation of the parent $\mathrm{PAH}$, which can occur during a combustion process or in the atmosphere. Many photochemical derivatives of PAH were found in the analysed aerosol samples. Their formation can be the result of three main processes: photochemical modifications of PAH adsorbed onto the particulate matter, spontaneous oxidation in the dark and chemical and particulate $\mathrm{PAH}$ modifications induced by reactions between gaseous pollutants $\left(\mathrm{NO}_{x}, \mathrm{SO}_{x}, \mathrm{O}_{3}\right)$, in the absence or presence of radiation. ${ }^{26} \mathrm{Oxy}-\mathrm{PAH}$ could also represent decomposition products of biopolymers like lignin. ${ }^{27}$ Table 1 lists some of the oxy-PAH detected as aerosol components in this study and in other recent works. In aerosols from Giesta, these oxy-PAHs were detected at trace levels, excepting the 2,6-di-tert-butyl-p-benzoquinone. Concentrations of this compound varied from $2 \mathrm{pg} \mathrm{m}^{-3}$, at night, to maximum levels of $2 \mathrm{ng} \mathrm{m}^{-3}$, during day.

In addition to PAH and oxy-PAH, nitrogen- and sulphur-containing heterocyclic polyaromatic hydrocarbons (aza arenes and thia arenes, respectively) have been identified. These compounds were detected before in urban atmospheres and in the exhaust emissions from several sources. ${ }^{31}$ Aza and thia arenes are formed during the combustion by incorporating $\mathrm{N}$ - and S- atoms into their ring structures. In this study, several aza and thia polyaromatic compounds have been identified. Some of the detected compounds in the Greek samples, containing nitrogen or sulphur, are listed in Table 2.

Table 1. Concentration $\left(\mathrm{ng} \mathrm{m}^{-3}\right)$ of particle-associated oxy-PAH at different sites

\begin{tabular}{|c|c|c|c|c|c|}
\hline & $\begin{array}{l}\text { Fir forest Pertouli, } \\
\text { Greece. This study }\end{array}$ & $\begin{array}{c}\text { Crete, Greece } \\
\text { Urban }^{28}\end{array}$ & $\begin{array}{c}\text { Munich, Germany } \\
\text { Urban }^{29}\end{array}$ & $\begin{array}{l}\text { Aveiro, Portugal } \\
\text { Urban }^{30}\end{array}$ & $\begin{array}{l}\text { Lisbon, Portugal } \\
\text { Urban }^{30}\end{array}$ \\
\hline 7H-benz(de)anthracene-7-one & $0.1-0.2$ & 1.9 & & $<7$ & $<7$ \\
\hline 7H-benz(de)fluorenon-7-one & $0.1-0.2$ & & & & \\
\hline 17H-cyclopenta(a)phenanthren-17-one & $0.1-0.2$ & & & & \\
\hline Cyclo(def)phenanthrenone & $0.1-0.2$ & & & $<7$ & $<7$ \\
\hline 9,10 -anthracenedione & & & $0.51-1.47$ & t.1. & t.1. \\
\hline 9H-fluoren-9-one & & & $0.22-0.46$ & t.1. & t.l. \\
\hline Benz(a)anthracene-7,12-dione & & & $0.16-0.85$ & t.l. & t.l. \\
\hline \multicolumn{6}{|l|}{ 7H-benzo(c)fluorenone } \\
\hline Naphthacene-5,2-one & & & & $1.2-1.5$ & \\
\hline 11H-benzo(a)fluorenone & & & $0.24-2.68$ & & \\
\hline 11H-benzo(b)fluorenone & & & $0.34-1.67$ & & \\
\hline Pyrenecarboxyaldehyde & $<5.4$ & & $1.07-5.05^{*}$ & & \\
\hline Phenanthrenecarboxyaldehyde & & $2.1-4.4$ & & & \\
\hline Quinones: & $<0.1-0.5$ & $0.3-4.0$ & & $<1$ & $<2$ \\
\hline \multicolumn{6}{|l|}{ 2,5-di-tert-p-anthraquinone } \\
\hline \multicolumn{6}{|l|}{ 2,6-di-tert-butyl-p-benzoquinone } \\
\hline \multicolumn{6}{|l|}{ 2-ethyl-anthraquinone } \\
\hline \multicolumn{6}{|l|}{ Hydroxyantraquinone } \\
\hline 5,6-dimethoxynaphtoquinone & & & & & \\
\hline
\end{tabular}

t.1. -trace level; * Pyrenecarboxyaldehyde + benz(de)anthracen-7-one. 
Table 2. N- and S- containing polyaromatic hydrocarbons detected in aerosols from Greece

\begin{tabular}{|c|c|c|c|}
\hline Name & Max. conc. $\left(\mathrm{pg} \mathrm{m}^{-3}\right)$ & Formula & CAS \\
\hline 2,3-Dihydrothiophene & 0.1 & $\mathrm{C}_{4} \mathrm{H}_{6} \mathrm{~S}$ & $001120-59-8$ \\
\hline 2,5-Dihydrothiophene & 0.1 & $\mathrm{C}_{4} \mathrm{H}_{6} \mathrm{~S}$ & $001708-32-3$ \\
\hline Pyrazine, tetraethyl & 3.6 & $\mathrm{C}_{12} \mathrm{H}_{20} \mathrm{~N}_{2}$ & $038325-19-8$ \\
\hline 1-Ethyldibenzothiophene & 67.4 & $\mathrm{C}_{14} \mathrm{H}_{12} \mathrm{~S}$ & 089816-97-7 \\
\hline 1-Benzyl-3-phenyl-2-pyrazoline & 2.8 & $\mathrm{C}_{16} \mathrm{H}_{16} \mathrm{~N}$ & $000729-19-1$ \\
\hline 1,2,4-Oxadiazole, 5-(2-methylphenyl)-3-phenyl- & 9.2 & $\mathrm{C}_{15} \mathrm{H}_{12} \mathrm{~N}_{2} \mathrm{O}$ & $054494-15-4$ \\
\hline 5,6-dihydro-3,5,6,8-tetramethylbenzo[c]cinnoline & 39.0 & $\mathrm{C}_{16} \mathrm{H}_{18} \mathrm{~N}_{2}$ & $104347-36-6$ \\
\hline Methyl-2-styryl[b]thiophene & 100.6 & $\mathrm{C}_{17} \mathrm{H}_{14} \mathrm{~S}$ & $084258-73-1$ \\
\hline 2,3-Dihydro-7-methyl-5-phenyl-1H-1,4-benzodiazepine-2-thione & 55.0 & $\mathrm{C}_{16} \mathrm{H}_{14} 4 \mathrm{~N}_{2} \mathrm{~S}$ & 002888-60-0 \\
\hline $11 \mathrm{H}$-Dibenzo[b,e][1,4]diazepin-11-one, 5-(3-aminopropyl)-5,10-dihydro- & 17.2 & $\mathrm{C}_{16} \mathrm{H}_{17} \mathrm{~N}_{3} \mathrm{O}$ & $013450-73-2$ \\
\hline Benzene, 1-(1,1-dimethylethyl)-2-methoxy-4-methyl-3,5-dinitro- & 0.8 & $\mathrm{C}_{12} \mathrm{H}_{16} \mathrm{~N}_{2} \mathrm{O}_{5}$ & 000083-66-9 \\
\hline 3,4,4,6-tetramethyl-2-(p-ethoxyphenylamino)-tetrahydro-1,3-oxazine & 32.5 & $\mathrm{C}_{16} \mathrm{H}_{24} \mathrm{~N}_{2} \mathrm{O}_{2}$ & 053004-26-5 \\
\hline Naphthalene, 2,6-dimethoxy-1,5-dinitro- & 5.6 & $\mathrm{C}_{12} \mathrm{H}_{10} \mathrm{~N}_{2} \mathrm{O}_{6}$ & 025314-97-0 \\
\hline 4H-3-(p-methylalinino)1-benzothiopyran-4-one, 1-oxide & 325.2 & $\mathrm{C}_{16} \mathrm{H}_{13} \mathrm{NO}_{2} \mathrm{~S}$ & $116884-81-2$ \\
\hline Dinaphtho $\left[1,2-b: 23^{\prime}-d\right]$ thiophene & 3.0 & $\mathrm{C}_{20} \mathrm{H}_{12} \mathrm{~S}$ & $000239-94-1$ \\
\hline Benzo[1,2-b:4,3-b']bisbenzo[b]thiophene & 348.0 & $\mathrm{C}_{18} \mathrm{H}_{10} \mathrm{~S}_{2}$ & 000192-24-9 \\
\hline
\end{tabular}

Many $n$-alkanals, furanones and carboxylic acids, which are thought to be oxidation products of alkenes, were detected in the aerosol samples. Alkenes constitute a significant fraction of VOC, especially in urban atmospheres. These hydrocarbons are relevant for ozone formation, since they can react with $\mathrm{O}_{3}, \mathrm{OH}$ and $\mathrm{NO}_{3}$. For alkenes with more than five carbons the reaction products may lead to SOA. In order to determine the molecular composition of SOA from 1-octene and 1-decene, Forstner and co-workers ${ }^{32}$ investigated the photo oxidation in the presence of nitrogen oxides via outdoor smog chamber. Heptanal, heptanoic acid and dihydro-5-propyl-2(3H)-furanone were the dominant organics identified in 1-octene aerosol. The detected species in 1-decene aerosol were nonanal, nonanoic acid, and dihydro-5-pentyl-2(3H)-furanone. Heptanal and nonanal result from the addition of ozone to the double bond in 1-octene and 1-decene, respectively. Ozone forms a 1,2,3-trioolane adduct which is decomposed into two excited Criegee biradicals and two aldehydes: heptanal/nonanal and formaldehyde. ${ }^{32,33}$ The excited biradicals may thermally stabilize or decompose to form other products, of which one path leads to the formation of heptanal/nonanal (Figure 1). However, these two compounds are formed as a result of two different reaction ways, and not only via bi-radicals paths. Heptanal and nonanal may also be formed from $\mathrm{OH}$ attack on the two alkenes. $\mathrm{OH}$ may add to either end of the double bond, but addition to the terminal carbon results in a more stable radical. If the addition is to the terminal carbon a more stable radical is formed. The $\beta$ hydroxyalkyl radical rapidly adds $\mathrm{O}_{2}$. The resulting radical ( $\beta$-hydroxyalkoxy) is decomposed to heptanal/ nonanal after $\mathrm{NO}$ to $\mathrm{NO}_{2}$ conversion. ${ }^{32}$ The mechanism is synthesised in Figure 2.

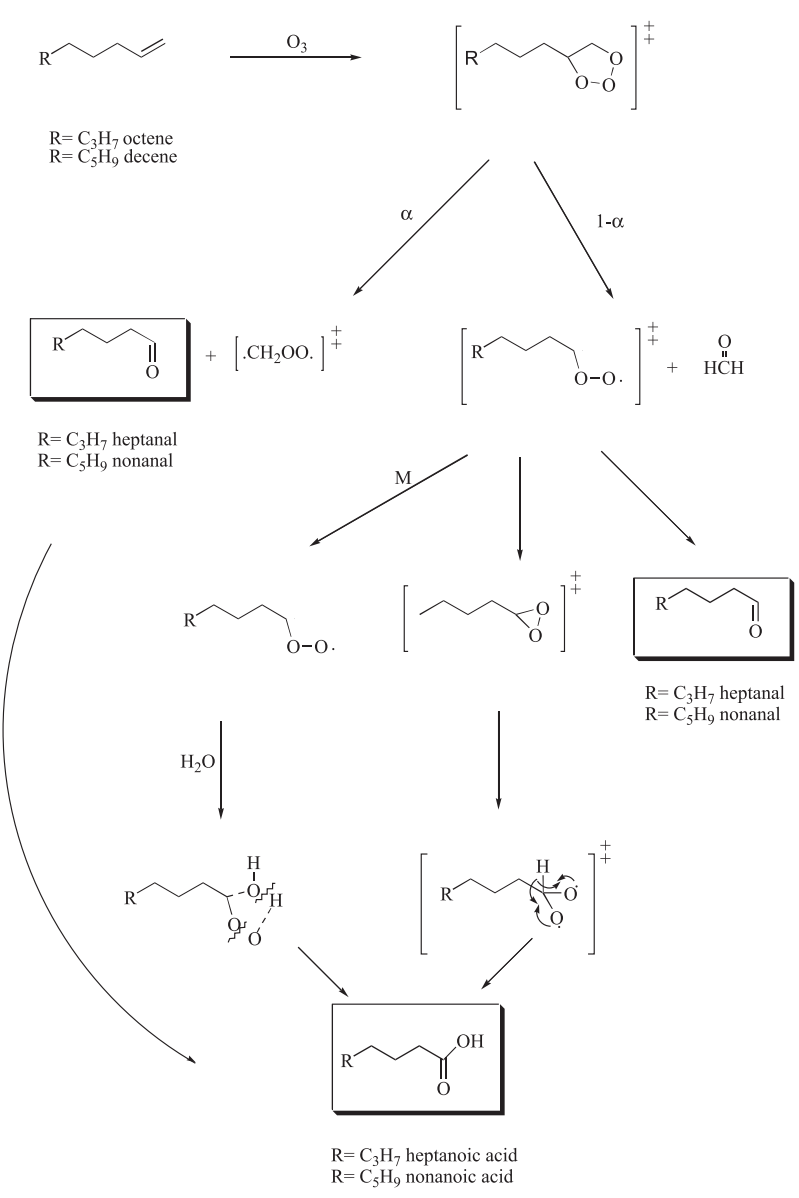

Figure 1. Mechanism of $\mathrm{O}_{3}$ addition to 1-octene/1-decene leading to heptanal/nonanal and heptanoic/nonanoic acids.

In addition to heptanal and nonanal, the SOA of 1-octene and 1-decene is composed of the corresponding acids. One possible pathway leading to the carboxylic acids formation is from the oxidation of the aldehydes. The $\mathrm{OH}$ radical may cause the $\mathrm{H}$-abstraction from the aldehyde and form a peroxy radical after $\mathrm{O}_{2}$ addition (Figure 3). The 


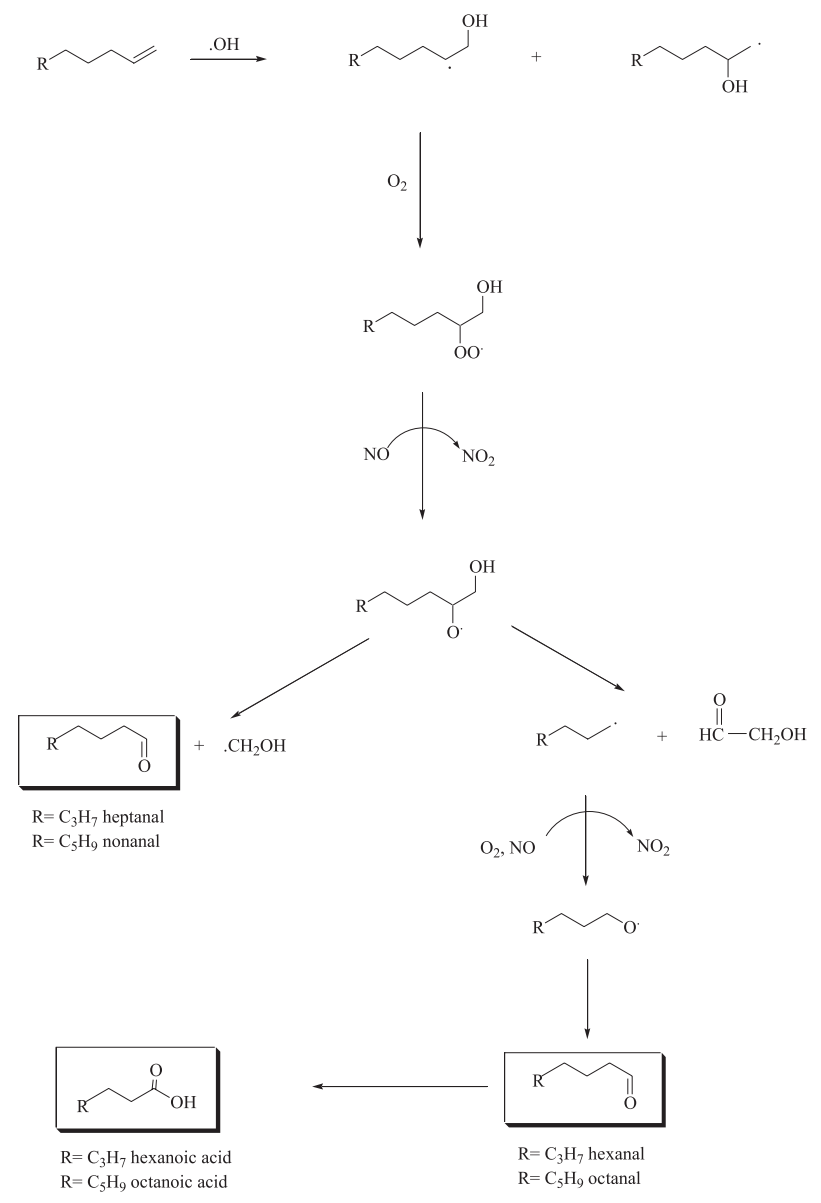

Figure 2. 1-Octene /1-Decene + OH radical pathway leading to heptanal/nonanal, hexanal/octanal and hexanoic/octanoic acids.

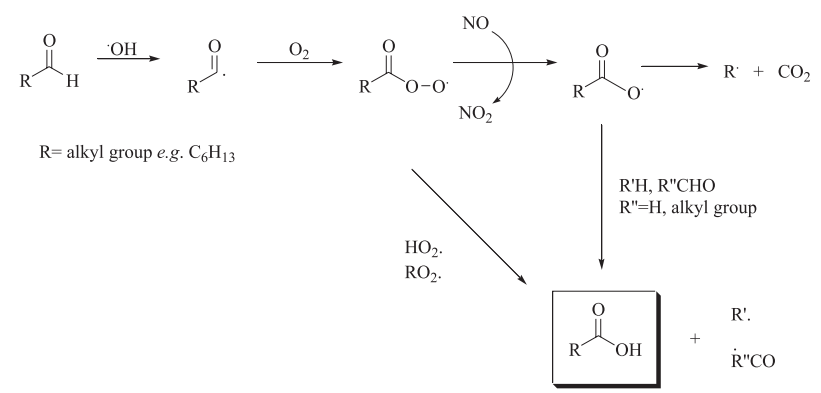

Figure 3. Oxidation of aldehydes leading to the corresponding carboxylic acids.

reaction of this radical with $\mathrm{NO}$ forms $\mathrm{NO}_{2}$ and an alkoxy radical, which can react with another alkene or aldehyde (e.g. heptanal/nonanal or formaldehyde). As a result of the $\mathrm{H}$-abstraction heptanoic/nonanoic acids are formed. Other mechanism leading to these acids involves the reaction of the peroxy radical, $\mathrm{RC}(\mathrm{O}) \mathrm{OO} \bullet$, with $\mathrm{HO}_{2} \bullet$ or $\mathrm{RO}_{2} \bullet$. Other route to explain the formation of $\mathrm{C}_{7}$ and $\mathrm{C}_{9}$ carboxylic acids is represented by the isomerisation of the thermally stable bi-radical that is included in the mechanism of $\mathrm{O}_{3}$ addition to the alkenes. This mechanism was described before.

Another mechanism by which octanal and decanal are formed is the reaction between the corresponding alkenes

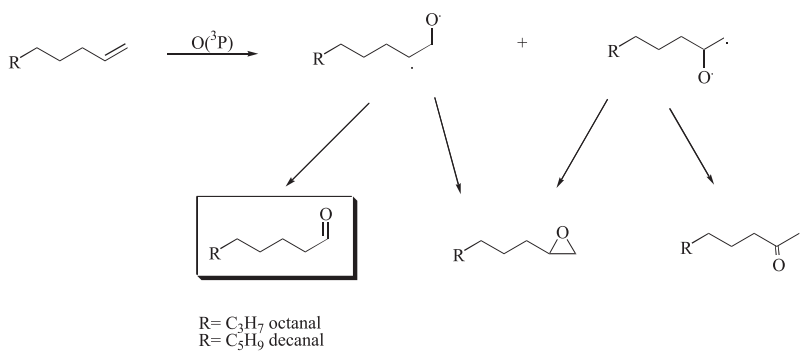

Figure 4. Possible mechanism leading to octanal and decanal from $\mathrm{O}\left({ }^{3} \mathrm{P}\right)$ addition to 1-octene and 1-decene.

and $\mathrm{O}\left({ }^{3} \mathrm{P}\right)$. The addition of $\mathrm{O}\left({ }^{3} \mathrm{P}\right)$ to the alkene leads to $1,2-$ epoxyoctane, 2-octanone, and the aldehydes ${ }^{34}$ (Figure 4).

As stated before, other dominant species in 1-octene and 1-decene aerosols are furanones. A possible mechanism leading to dihydro-5-propyl-2(3H)-furanone and dihydro5-pentyl-2(3H)-furanone from heptanal and nonanal was proposed by Wang and co-workers. ${ }^{35}$ According to this mechanism, the $\mathrm{OH}$ radical with subsequent oxygen addition attacks alkenes. Lactones are formed after cyclization of the $\alpha$-carbonyl alkoxy radical, which is a result of the Criegee biradical (Figure 5).

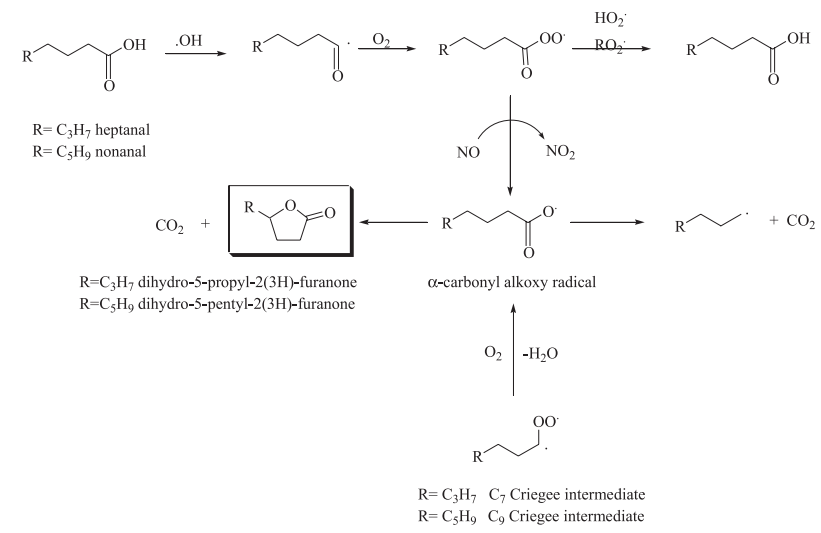

Figure 5. Mechanism of heptanal/nonanal oxidation to dihydro-5propyl-2(3H)-furanone/dihydro-5-pentyl-2(3H)-furanone.

Lactones are easily formed from $\gamma$-hydroxycarboxylic acids, which derive from the photo oxidation of alkenes. When there are numerous alkyl substituents on the lactone, the equilibrium is readily shifted to its formation even in the presence of small amounts of the corresponding acid. ${ }^{36}$

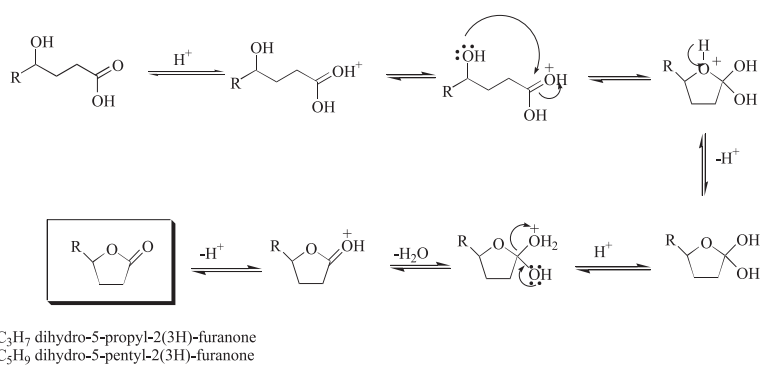

Figure 6. Cyclization of $\gamma$-hydroxycarboxylic acid to its lactone. 


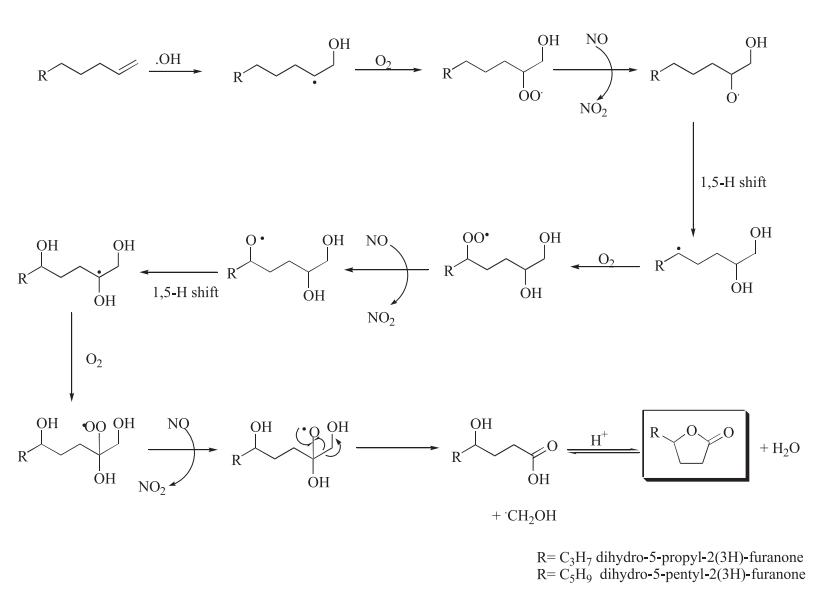

Figure 7. 1-Alkene/OH reaction leading to $\gamma$-hydroxycarboxylic acid and its lactone.

The mechanism of lactone formation from the $\gamma$-hydroxycarboxylic acid is presented in Figure 6.

As suggested earlier, the $\gamma$-hydroxycarboxylic acid can be derived from $\mathrm{OH}$ attack on the alkene and an alkyl radical is formed (Figure 7). Oxygen is added to this radical originating an alkylperoxy radical, which is transformed to an alkoxy radical after the conversion nitric oxide/ nitrogen dioxide. Then, a 1,5-hydrogen shift occurs and a dihydroxyalkyl radical is created. This radical reacts with oxygen and nitric oxide forming a dihydroalkoxy radical. After another 1,5-hydrogen shift a trihydroxyalkyl radical is formed, which adds oxygen to create a trihydroxyalkylperoxy radical. Reaction with nitric oxide converts this radical to the trihydroxyalkoxy radical, which subsequently rearranges and loses $\mathrm{CH}_{2} \mathrm{OH}$ to create the $\gamma$-hydroxycarboxylic acid. ${ }^{32}$

Among the analysed organics from various classes, octanoic acid, nonanoic acid, decanoic acid, $\gamma$-hydroxycarboxylic acids, heptanal, octanal, nonanal, decanal and some lactones were identified in the Greek aerosol. In addition to primary sources, the photo oxidation and subsequent gas-to-particle conversion of the reaction products of alkenes such as 1-octene, 1-nonene, 1-decene could contribute to the ambient levels. Particles from Giesta and Pertouli contained the homologous sequence of these cyclic ketones from dihydro-2(3H)-furanone to dihydro-5-tetradecyl-2(3H)-furanone at concentrations lower than $0.3 \mathrm{ng} \mathrm{m}^{-3}$. The Greek samples showed as predominant homologs the dihydro-5-heptyl-2(3H)furanone and the dihydro-5-octyl-2(3H)-furanone at levels close to $1.5 \mathrm{ng} \mathrm{m}^{-3}$.

Aerosol samples from Giesta and Pertouli also contained some heterocyclic diketones, at concentrations $<1 \mathrm{ng} \mathrm{m}^{-3}$. The predominant compounds were the dihydro-5-dodecyl2,5-furandione and the dihydro-5-tetradecyl-2,5-furandione. In simulator chambers, the 2,5-furandiones were detected as

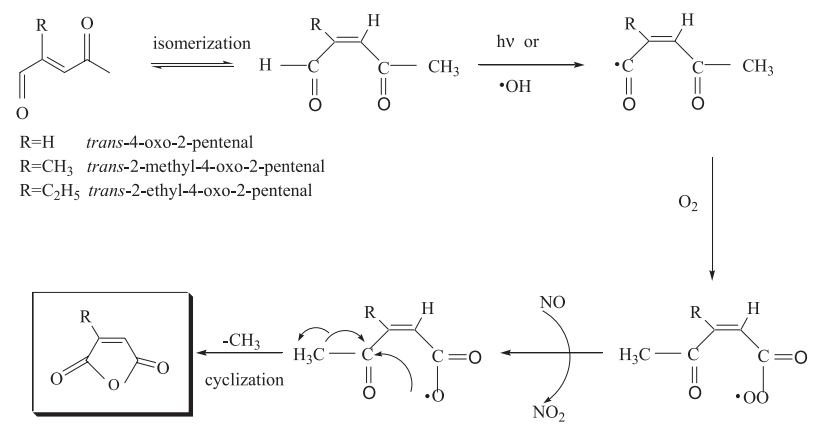

$\mathrm{R}=\mathrm{H} \quad$ 2,5-furandione

$\begin{array}{ll}\mathrm{R}=\mathrm{H} & 2,5-\text { furandione } \\ \mathrm{R}=\mathrm{CH}_{3} & \text { 3-methyl-2,5-furandione }\end{array}$ $\mathrm{R}=\mathrm{CH}_{3} 3$-methyl-2,5-furandione
$\mathrm{R}=\mathrm{C}_{2} \mathrm{H}_{5}$ 3-ethyl-2,5-furandione

Figure 8. Formation of furandiones from oxo-pentenals.
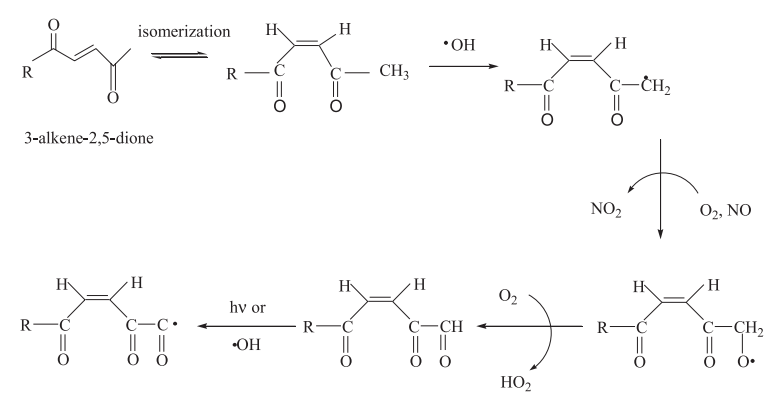

$\mathrm{O}_{2}, \mathrm{NO} \mathrm{NO}_{2}$
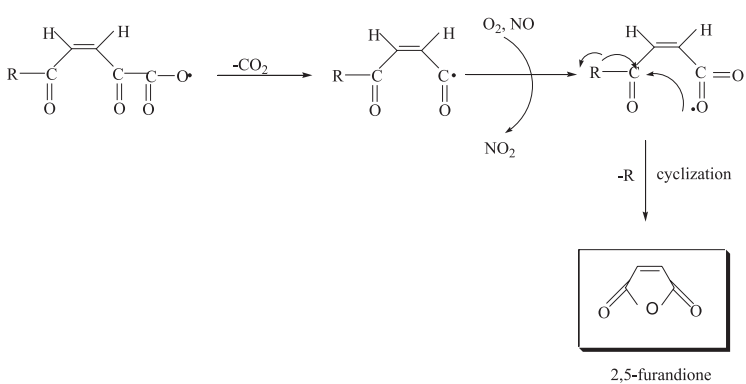

Figure 9. Formation of 2,5-furandiones from 3-alkene-2,5-diones.

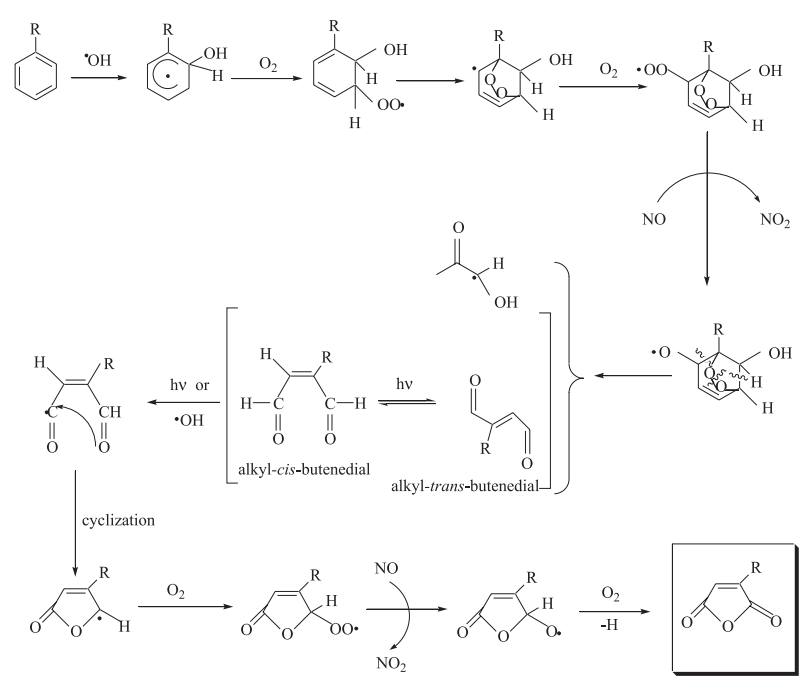

alkyl-2,5-furandione

Figure 10. Formation of 2,5-furandiones from alkyl-toluenes. 
secondary components from the photo oxidation of oxocarbonyls (Figure 8), unsaturated dicarbonyls (Figure 9) or aromatic compounds in the gaseous phase (Figure 10). The mechanism by which oxo-carbonyls can form 2,5furandiones involves the initial loss of the hydrogen adjacent to the carbonyl group by photolysis or $\mathrm{OH}$ abstraction. Subsequent addition of oxygen to the alkyl radical, formation of an alkoxy radical and cyclization lead to 2,5furandiones. ${ }^{36}$ Once in the particulate phase, the 2,5furandiones could be photolytically excited and form biradicals by splitting the double bond. The interaction between water vapour, nitro-phenols and these bi-radicals facilitates the proton changes and the rapid formation of dihydro-alkyl-2,5-furandiones ${ }^{36}$ (Figure 11).

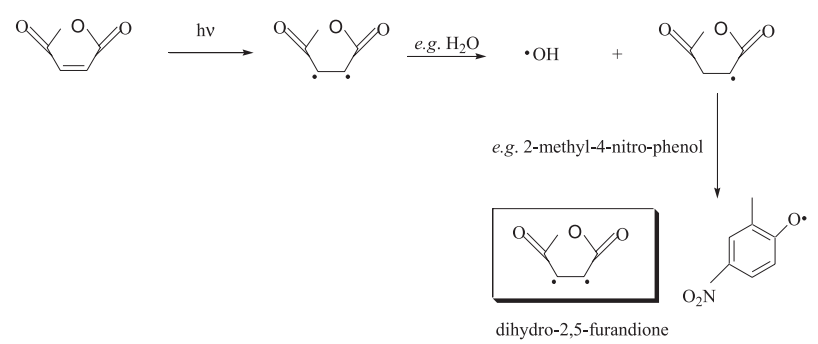

Figure 11. Reaction mechanism induced by light leading to the formation of dihydro-2,5-furandiones from 2,5-furandiones.

Oxo-carboxylic acids represent another group of organic compounds detected in the aerosols. They are likely photo oxidation products from cyclic olefins and unsaturated fatty acids. As examples, we have the $\mathrm{C}_{5}$ and $\mathrm{C}_{6}$ homologues, formed by oxidation of anthropogenic cyclic olefins, and the $\mathrm{C}_{8}$ and $\mathrm{C}_{9}$ compounds which are created by photo-oxidation of unsaturated carboxylic acids such as the oleic $\left(\mathrm{C}_{18: 1}\right)$ and linoleic $\left(\mathrm{C}_{18: 2}\right)$ acids. ${ }^{28}$ Products like the 9-oxononanoic acid methyl ester (methyl azelaic semialdehyde) and the nonanedioic dimethyl ester (azelaic acid dimethyl ester), both detected in all aerosol samples at levels lower than $5 \mathrm{ng} \mathrm{m}^{-3}$, form the final reaction products of the oleic acid with ozone ${ }^{37}$, according to the scheme showed in Figure 12. Yokouchi and Ambe ${ }^{38}$ suggested another reaction pathway to explain the formation of azelaic acid. Since oleic and linoleic acids are ubiquitous and both of them have a double bond at the ninth carbon from their carboxyl group, the ozonolysis of these acids would cause Criegee split at that ninth position, producing azelaic acids. Considering that the referred precursor compounds and the reaction products are all present in samples from the two sampling sites, it is probable that the two reaction pathways have occurred concomitantly.

The detection in the particulate phase of 3-furanoacetic acid, tetrahydro-2-methoxy-4,5-dimethyl and other furan-

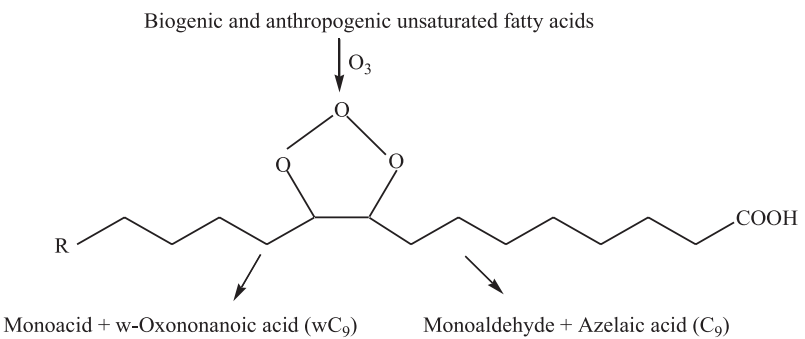

Figure 12. Reaction scheme explaining the formation of azelaic semialdehyde and azelaic acid.

type compounds is likely associated with a precursor, the furfural, which is a component of diesel emission and plant vapour. ${ }^{38}$ These furan derivatives may also originate from the oxidation of isoprene. ${ }^{38}$ Some keto-carboxylic acids were also detected (e.g. 4-oxo-pimelic acid) which may be produced photochemically from hydrocarbon precursors.

Among the SOA products detected in samples from Pertouli, at levels close to $1 \mathrm{ng} \mathrm{m}^{-3}$, was the $\mathrm{C}_{9}$ dioxocarboxylic acids, which may result from the ozonolysis of limonene (Figure 13). ${ }^{33,39}$ Adipic acid (hexanedioic acid) has been reported as a product of the ozonolysis of $\alpha$-pinene in smog chambers. ${ }^{40,41}$ This compound was also identified in the Giesta and Pertouli samples at levels ranging from 0.01 to $10.93 \mathrm{ng} \mathrm{m}^{-3}$. Glutaric acid (pentanedoic acid) was present in our samples at concentrations ranging from trace levels to maximum values of $8.84 \mathrm{ng} \mathrm{m}^{-3}$. This last alkanedioic acid was identified in a smog chamber investigation as a product of the ozonolysis of pinenes. ${ }^{40}$ In other laboratory experiment, Wängberg et $a l .^{42}$ observed the formation of pinane epoxide from the $\alpha$-pinene/ $\mathrm{NO}_{3}$ reaction (Figure 14). This secondary compound was also present in some Greek samples not exceeding $0.73 \mathrm{ng} \mathrm{m}^{-3}$. Pinic acid constitutes another secondary compound detected in the particulate matter. Laboratory experiments have revealed that its formation may be explained by two different mechanisms: (i) $\alpha$-pinene ozonolysis (Figure 15),,$^{13,40,41,43-51}$ (ii) oxidation of $\beta$-pinene by $\mathrm{O}_{3} / \mathrm{NO}_{\mathrm{x}}$ (Figure 16). ${ }^{47,52-54}$ Pinonaldehyde and pinonic acid were detected in many samples from Portugal and Greece. In laboratory experiments with $\alpha$-pinene and $\mathrm{OH}$ radicals, ozone, or $\mathrm{NO}_{\mathrm{x}}$ the formation of these products was observed. ${ }^{13,33,38,41,55-60}$ Mechanisms leading to the formation of these products are shown in Figures 15 and 17. The aldehyde may also take place in the particulate phase by oxidation of $\alpha$-pinene through reaction with other oxidising species such as $\mathrm{NO}_{3}$ and $\mathrm{N}_{2} \mathrm{O}_{5} \cdot{ }^{30}$ Recently, Lee et $a l .{ }^{61}$ have detected pinonaldehyde and pinonic acid, in smog chamber experiments, as particulate products from the photo-oxidation of $\alpha$-pinene in the presence of $\mathrm{NO}_{x}$ and diesel soot. 


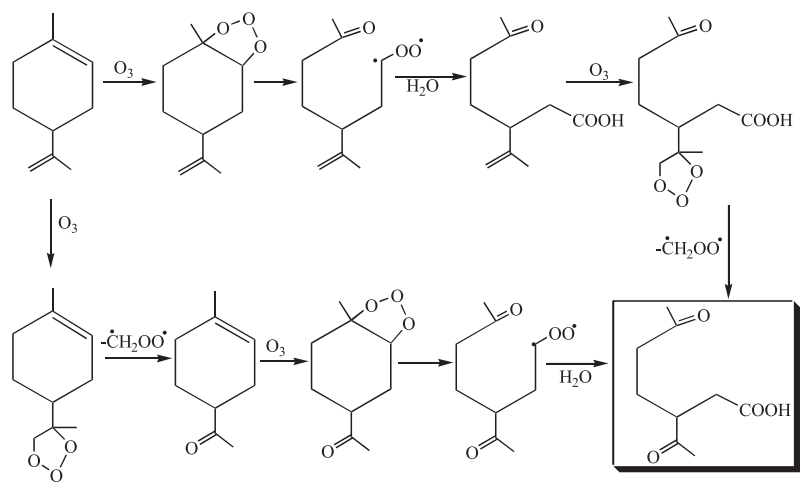

Figure 13. Formation of dioxo-nonanoic acid from the ozonolysis of limonene.
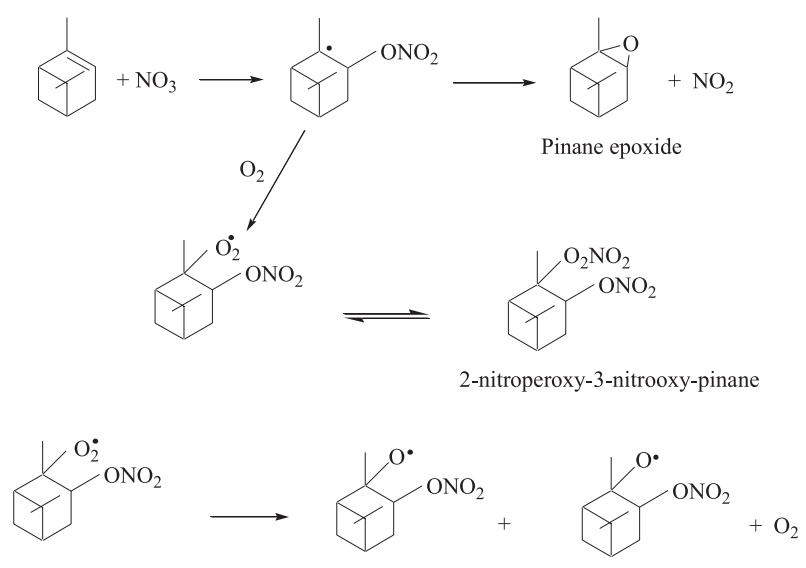

$y^{\mathrm{O}_{2}} \mathrm{ONO}_{2}^{\mathrm{O}} \mathrm{ONO}^{2}+\mathrm{NO}_{2}+\mathrm{O}_{2}$

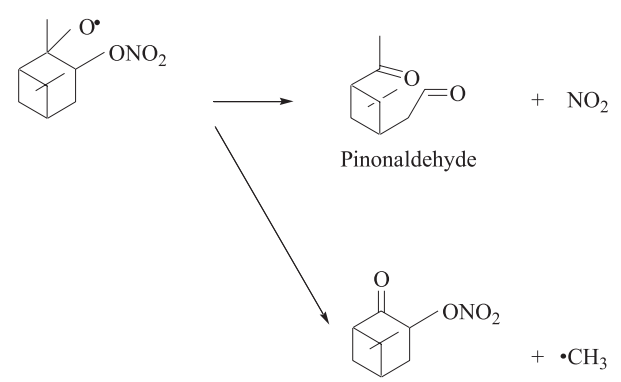

Figure 14. Reaction mechanisms for the oxidation of $\alpha$-pinene by $\mathrm{NO}_{3}$ leading to the formation of pinane epoxide and pinonaldehyde

The major product from the $\beta$-pinene oxidation identified in the particulate matter was the nopinone. This compound has been detected in laboratory studies as a product of the precursor through reaction with $\mathrm{O}_{3}$ or $\mathrm{OH}^{33,38,47,53-57,60,62,63} \mathrm{The}$ formation of nopinone may also take place after oxidation of $\beta$-pinene by $\mathrm{NO}_{x},{ }^{33,63} \mathrm{O}_{3} / \mathrm{NO}_{\mathrm{x}}{ }^{52}$ or $\mathrm{NO}_{\mathrm{x}} / \mathrm{SO}_{2}{ }^{64}$ Figure 18 shows the mechanisms, which are initialised by the ozonolysis of $\beta$ pinene, leading to the formation of nopinone. It should be noted that nopinone, pinonaldehyde, pinonic acid and pinic acid have already been identified by Kavouras and co-

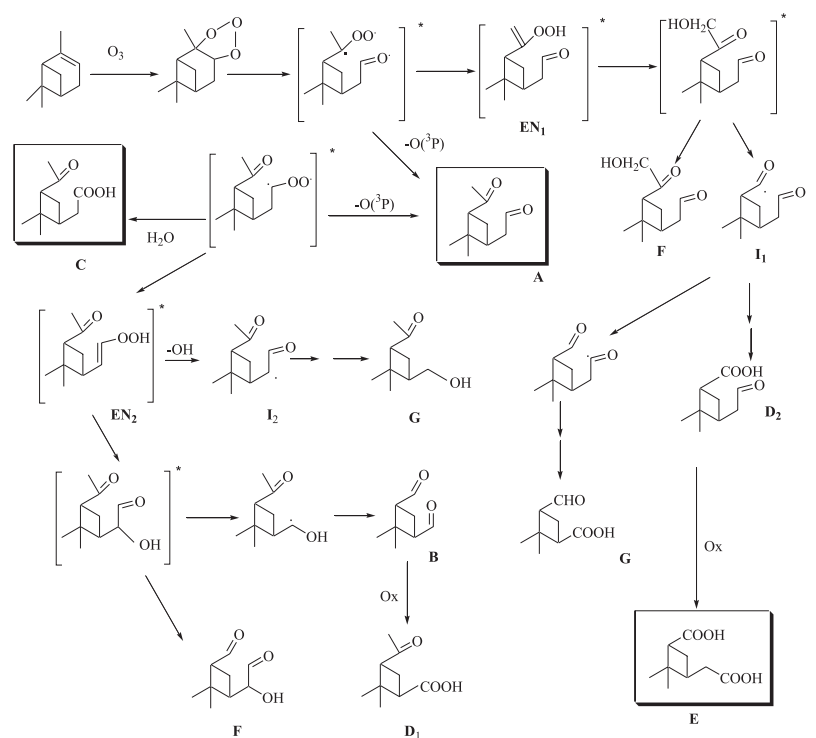

Figure 15. Mechanism for the $\alpha$-pinene/ $\mathrm{O}_{3}$ reactions. (*) - energyrich species; A - pinonaldehyde; $\mathbf{B}$ - norpinonaldehyde; $\mathbf{C}$ - pinonic acid; $\mathbf{D}_{1}, \mathbf{D}_{2}$ - isomers of norpinonic acid; $\mathbf{E}$ - pinic acid; $\mathbf{E N}_{1}-$ enehydroxyperoxide; $\mathbf{E N}_{2}$ - enehydroperoxide; $\mathbf{F}-\mathrm{C}_{10}$ hydroxy dicarbonyls; G - 1-acetyl-2,2-dimethyl-3-hydroxymethylcyclobutane or 2,2-dimethyl-3-formyl-cyclobutane formic acid; $\mathbf{I}_{1}$ - intermediate resulting from decomposition of $\mathbf{E N}_{1} ; \mathbf{I}_{2}$ - intermediate resulting from the loss of an $\mathrm{OH}$ radical from $\mathbf{E N}_{2}^{2}$

workers ${ }^{65-67}$ in aerosol samples collected in parallel during this AEROBIC campaign. The concentrations determined in our measurements for pinonaldehyde (0.12-0.87 $\left.\mathrm{ng} \mathrm{m}^{-3}\right)$ and nopinone (0.02-0.59 $\left.\mathrm{ng} \mathrm{m}^{-3}\right)$ are comparable to those of Kavouras et al. ${ }^{67}$ for the same forest, who presented concentrations in the range $0.3-1.2 \mathrm{ng} \mathrm{m}^{-3}$ and $0.0-0.4 \mathrm{ng} \mathrm{m}^{-}$ ${ }^{3}$, respectively. However, while our pinonic and pinic acids maximum concentrations are close to $1 \mathrm{ng} \mathrm{m}^{-3}$, these investigators reported maximum levels of 25.7 and $4.4 \mathrm{ng} \mathrm{m}^{-}$ ${ }^{3}$, respectively. A possible explanation for this discrepancy may be related with the fact that the Greek group uses shorter sampling times, which permit the identification of peak concentrations that are averaged in our long-term samples. Another explanation is the volatilisation of these semi-volatile compounds from our filters during sampling. In fact, atmospheric measurements may be biased due to sampling artifacts resulting from the use of samplers designed mainly for the collection of non-volatile species. These artifacts include the volatilisation of particle-associated species under the sub atmospheric pressures within the samplers. ${ }^{68,69}$ Poster et al.$^{69}$ evaluated the magnitude of volatilisation of PAH from particles during sampling and found losses between 21 and $33 \%$ of the lower molecular weight compounds.

Previous field measurements of particulate phase terpene oxidation products have detected pinonaldehyde, nopinone, pinonic acid and pinic acid. Satsumabayashi et al. $^{70}$ measured pinonaldehyde levels of $30 \mathrm{~m}^{-3}$ and $100 \mathrm{ng} \mathrm{m}^{-3}$ in two Japanese mountains. 


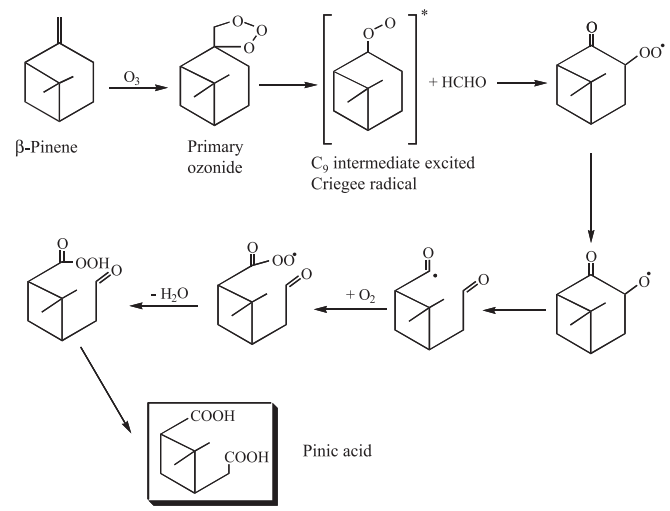

Figure 16. Pinic acid formation from the ozonolysis of $\beta$-pinene

Calogirou et al. ${ }^{71}$ detected this aldehyde near Ispra, Italy, at $90 \mathrm{ng} \mathrm{m}^{-3}$. Yu et al. ${ }^{46}$ reported concentrations for pinonaldehyde, pinic acid and pinonic acid ranging from 0.2-1.0, 0.5-0.6, 0.1-0.8 $\mathrm{ng} \mathrm{m}^{-3}$, respectively, in filter samples collected in Kejimkujik National Park (Nova Scotia) and San Bernardino National Forest (California). Kavouras et al. ${ }^{65}$ observed pinonaldehyde $\left(0.2-32.1 \mathrm{ng} \mathrm{m}^{-3}\right)$, nopinone $\left(0.0-13.2 \mathrm{ng} \mathrm{m}^{-3}\right)$, cispinonic acid (7.1-60.1 $\left.\mathrm{ng} \mathrm{m}^{-3}\right)$ and trans-pinonic acid (1.5-42.9 $\left.\mathrm{ng} \mathrm{m}^{-3}\right)$ in the particulate matter from a eucalyptus forest in Portugal. Nopinone, pinonaldehyde, pinonic acid and pinic acid were measured at average levels of $2.4,13.7,25.3$ and $15.8 \mathrm{ng} \mathrm{m}^{-3}$, respectively, in samples from Aveiro, Portugal. ${ }^{30}$ Concentrations of $6.6,12.5$ and $7.5 \mathrm{ng} \mathrm{m}^{-3}$ were obtained for pinonaldehyde, pinonic acid and pinic acid, respectively, in Finish aerosols collected in Hyytiälä. ${ }^{30}$

Another product of the $\beta$-pinene $/ \mathrm{NO}_{\mathrm{x}}$ reaction also detected in the present investigation was pinocamphone. ${ }^{63}$ In aerosol samples from smog chamber studies with sabinene and $\mathrm{OH} / \mathrm{O}_{3}$, sabinaketone was identified as secondary product. ${ }^{43}$ More recently, Larsen et al. ${ }^{60}$ have also detected

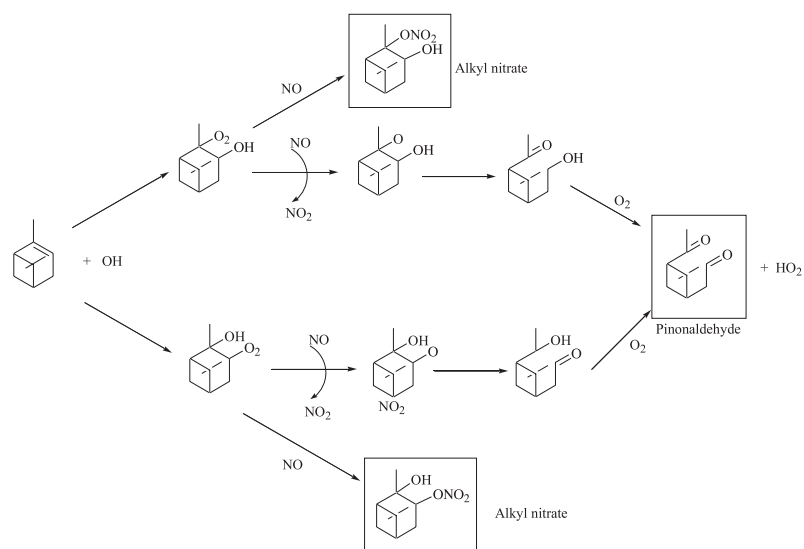

Figure 17. Oxidation of $\alpha$-pinene by $\mathrm{OH}$ leading to the formation of pinonaldehyde

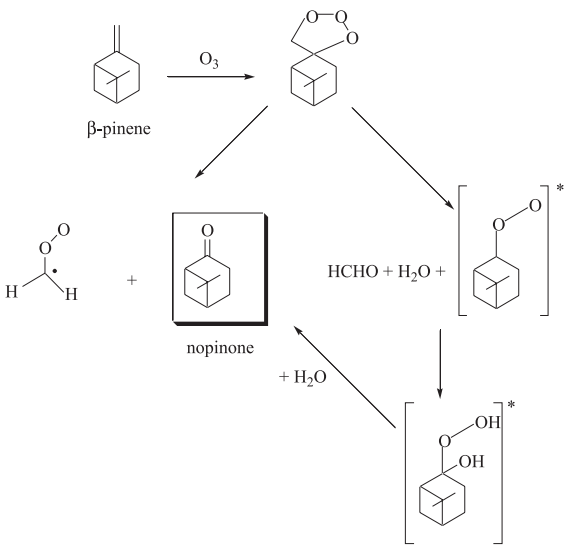

Figure 18. Reaction mechanism leading to the formation of nopinone from the ozonolysis of $\beta$-pinene

sabinaketone in aerosols from laboratory experiments with the terpenic precursor and $\mathrm{OH}$. This ketone was also present in some samples from our in situ experiments. The pinocamphone concentrations ranged from 0.00 to $1.13 \mathrm{ng}$ $\mathrm{m}^{-3}$ and sabinaketone from 0.14 to $2.50 \mathrm{ng} \mathrm{m}^{-3}$. The observation at trace levels of sabinaketone was already done by Alves $e t$ al. ${ }^{17}$ in atmospheric aerosols from Aveiro, Lisbon and Hyytiälä.

The formation of a terpinolene product has been reported by Arey et al. ${ }^{72}$ and Hakola et al..$^{55}$ after smog chamber experiments. This compound, observed in the Greek aerosol, is 4-methyl-3-cyclohexen-1-one and results from the oxidation of the $\mathrm{VOC}$ by $\mathrm{OH} / \mathrm{O}_{3}$. Its concentrations were always lower than $0.05 \mathrm{ng} \mathrm{m}^{-3}$.

Some of the secondary compounds are quite volatile and are not expected to be present in the particulate phase at gaseous concentration values that are typically lower than saturation. Dissolution to less volatile particulate liquid organic mixtures, following Raoult's law may be the explanation for our findings. ${ }^{73}$ The total carbonyl products of biogenic VOC have values ranging from 6 to $50 \mathrm{ng} \mathrm{m}^{-3}$. These concentrations account for $1.5 \%$, on average, of the total organic compounds mass. It can be seen from Figure 19 that there is a clear daily variability with minimum concentrations during night and maxima during day.

\section{Acknowledgements}

Measurements were made as part of the European Commission project "Aerosols formation from biogenic organic carbon" (AEROBIC). We acknowledge the "Fundação para a Ciência e a Tecnologia" for financial support through the grant PRAXIS XXI/9622/96. In addition, we are grateful to Doctor E. Stephanou from the University of Crete, Greece, who kindly provided information concerning analytical methodologies to study the organic aerosol speciation. 

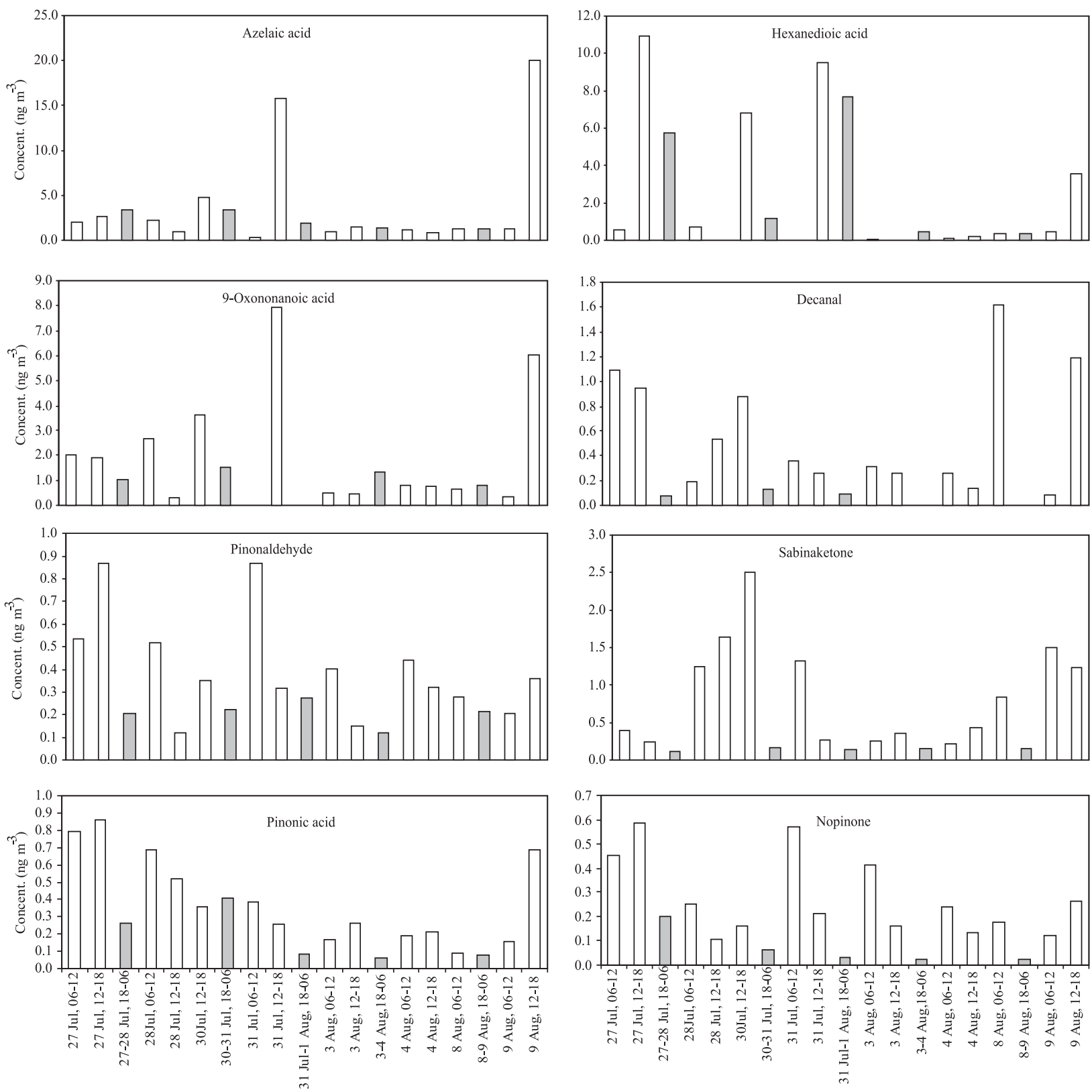

\section{$\square$ Diurnal levels $\quad \square$ Nocturnal levels}

Figure 19. Concentration variability of some photo-oxidation products detected in samples from Pertouli.

\section{References}

1. Bowman, F. M.; Pilinis, C.; Seinfeld, J. H.; Atmos. Environ. 1995, 29, 579.

2. Barthelmie, R. J.; Pryor, S. C.; Sci. Total Environ. 1997, 205, 167.

3. Matsumoto, K.; Tanaka, H.; Nagao, I.; Ishizaka, Y.; Geophys. Res. Lett. 1997, 24, 655.

4. IPCC (Intergovernmental Panel on Climate Change); Climate Change 1994, Cambridge University Press: New York, 1995.
5. Saxena, P.; Hildemann, L. M.; McMurry, P. H.; Seinfeld, J. H.; J. Geophys. Res. 1995, 100, 18755.

6. Brown, J. R.; Field, R. A.; Goldstone, M. E.; Lester, J. N.; Perry, R.; Sci. Total Environ. 1996, 177, 73.

7. Dyremark, A.; Westerholm, R.; Överik, E.; Gustavsson, J.-A.; Atmos. Environ. 1995, 29, 1553.

8. Kawanaka, Y.; Matsumoto, E.; Sakamoto, K.; Wang, N.; Yun, S.-J.; Atmos. Environ. 2004, 38, 2125.

9. Isidorov, V. A.; Organic Chemistry of the Earth's Atmosphere, Springer-Verlag: Berlim, 1990. 
10. Pandis, S. N.; Harley, R. A.; Cass, G. R.; Seinfeld, J. H.; Atmos. Environ. 1992, 26A, 2269.

11. Pankow, J. F.; Atmos. Environ. 1994, 28, 185.

12. Pankow, J. F.; Atmos. Environ. 1994, 28, 189.

13. Yu, J.; Flagan, R.; Seinfeld, J.; Environ. Sci. Technol. 1998, 32, 2357.

14. Saxena, P.; Hildemann, L. M.; J. Atmos. Chem. 1996, 24, 946.

15. Guicherit, R.; Sci. Total Environ. 1997, 205, 201.

16. http://www.crcao.com/annualreport/impacts/a41.htm, accessed in May, 2004

17. Cheng, Y.; Li, S.-M.; Leithead, A.; Brickell, P. C.; Leaitch, R. W.; Atmos. Environ. 2004, 38, 5789.

18. Shantz, N. C.; Aklilu, Y.-A.; Ivanis, N.; Leaitch, W. R.; Brickell, P. C.; Brook, J. R.; Cheng, Y.; Halpin, D.; Li, S.-M.; Tham, Y. A.; Toom-Sauntry, D.; Prenni, A. J.; Graham, L.; Atmos. Environ. 2004, 38, 5849.

19. Seinfeld, J. H.; Pankow, J. F.; Annu. Rev. Phys. Chem. 2003, 54,121

20. Alves, C.; Pio, C.; Duarte, A.; Atmos. Environ. 2001, 35, 5485.

21. Harrison, D.; Hunter, M.C.; Lewis, A.C.; Seakins, P. W.; Bonsang, B.; Gros, V.; Kanakidou, M.; Touaty, M.; Kavouras, I.; Mihalopoulos, N.; Stephanou, E.; Alves, C.; Nunes T.; Pio, C.; Atmos. Environ. 2001, 35, 4699.

22. Stephanou, E.; Stratigakis, N.; J. Chromatogr. A 1993, 644, 141.

23. Gogou, A.; Apostolaki, M.; Stephanou, E.; J. Chromatogr. A 1998, 799, 215.

24. Minoia, C.; Magnaghi, S; Micoli, G.; Fiorentino, M. L.; Turci, R.; Angeleri S.; Berri, A.; Sci. Total Environ. 1997, 198, 33.

25. Kalaitzoglou, M.; Terzi, E.; Samara, C.; Atmos Environ. 2004, $38,2545$.

26. Valerio, F.; Bottino, P.; Ugolini, D.; Cimberle, M. R.; Tozzi, G. A.; Frigerio, A.; Sci. Total Environ. 1984, 40, 169.

27. Rogge, W. F.; Hildemann, L. M.; Mazurek, M. A.; Cass, G. R.; Simoneit, B. R. T.; Environ. Sci. Technol. 1998, 32, 13.

28. Gogou, A.; Stratigakis, N.; Kanakidou, M.; Stephanou, E.; Org. Geochem. 1996, 25, 79.

29. Schnelle-Kreis, J.; Gebefügi, I.; Welzl, G.; Jaensch, T.; Kettrup, A.; Atmos. Environ. 2001, 35, S71.

30. Alves, C.; Carvalho, A.; Pio, C.; J. Geophys. Res. 2002, 107, 8345.

31. Rogge, W. F.; Hildemann, L. M.; Mazurek, M. A.; Cass, G. R.; Simoneit, B. R. T.; Environ. Sci. Technol. 1993, 27, 2736.

32. Forstner, H.; Flagan, R.; Seinfeld, J.; Atmos. Environ. 1997, $31,1953$.

33. Grosjean, D.; Williams, E. L.; Seinfeld, J. H.; Environ. Sci. Technol. 1992, 26, 1526.

34. Paulson, S. E.; Seinfeld, J. H.; Environ. Sci. Technol. 1992, 26, 1165.

35. Wang, S. C.; Paulson, S. E.; Grosjean, D.; Flagan, R. C.; Seinfeld, J. H.; Atmos. Environ. 1992, 26A, 403.
36. Forstner, H. J. L.; Flagan, R. C.; Seinfeld, J. H.; Environ. Sci. Technol. 1997, 31, 1345.

37. Rogge, W. F.; Mazurek, M. A.; Hildemann, L. M.; Cass, G. R.; Simoneit, B. R. T.; Atmos. Environ. 1993, 27A, 1309.

38. Yokouchi, Y.; Ambe Y.; Atmos. Environ. 1985, 19, 1271.

39. Neeb, P.; Sauer, F.; Horie, O.; Atmos. Environ. 1997, 31, 1417.

40. Hoffmann, T.; Odum, J. R.; Bowman, F.; Collins, D.; Klockow, D.; Flagan, R. C.; Seinfeld, J. H.; J. Atmos. Chem. 1997, 26, 189.

41. Koch, S.; Winterhalter, R.; Uherek, E.; Kolloff, A.; Neeb, P.; Moortgat, G. K.; Atmos. Environ. 2000, 34, 4031.

42. Wängberg, I.; Barnes, I.; Becker, K. H.; Environ. Sci. Technol. 1997, 31, 2130.

43. Christoffersen, T. S.; Hjorth, J.; Horie, O.; Jensen, N. R.; Kotzias, D.; Molander, L. L.; Neeb, P.; Ruppert, L.; Winterhalter, R.; Virkkula, A.; Wirtz, K.; Larsen, B. R.; Atmos. Environ. 1998, $32,1657$.

44. Hoffmann, T.; Bandur, R.; Marggraf, U.; Linscheid, M.; $J$. Geophys. Res. 1998, 103, 25569.

45. Yu, J.; Cocker III, D. R.; Griffin, R. J.; Flagan, R. C.; Seinfeld, J. H.; J. Atmos. Chem. 1999, 34, 207.

46. Yu, J.; Griffin, R. J.; Cocker, D. R.; Flagan, R. C.; Seinfeld, J. H.; Blanchard, P.; Geophys. Res. Lett. 1999, 26, 1145.

47. Winterhalter, R.; Neeb, P.; Moortgat, G.; Proceedings of the European Geophysical Society XXIII General Assembly, Nice, 1998.

48. Winterhalter, R.; Neeb, P.; Grossmann, D.; Kolloff, A.; Horie, O.; Moortgat, G.; J. Atmos. Chem. 2000, 35, 165.

49. Glasius, M.; Duane, M.; Larsen, B. R.; J. Chromatogr. A 1999, 833, 121.

50. Jang, M.; Kamens, R. M.; Atmos. Environ. 1999, 33, 459.

51. Iinuma, Y.; Böge, O.; Gnauk, T.; Herrmann, H.; Atmos. Environ. 2004, 38, 761.

52. Palen, E. J.; Allen, D. T.; Pandis, S. N.; Paulson, S. E.; Seinfeld, J. H.; Flagan, R. C.; Atmos. Environ. 1992, 26A, 1239.

53. Jaoui, M.; Kamens, R. M.; J. Atmos. Chem. 2003, 43, 101.

54. Jaoui, M.; Kamens, R. M.; J. Atmos. Chem. 2003, 44, 259.

55. Hakola, H.; Arey, J.; Aschmann, S. M.; Atkinson, R. J.; Atmos. Chem. 1994, 18, 75.

56. Hatakeyama, S.; Isumi, K.; Fukuyama, T.; Akimoto, T.; J. Geophys. Res. 1989, 94, 13013.

57. Hatakeyama, S.; Izumi, K.; Fukuyama, T.; Akimoto, H.; Washida, N.; J. Geophys. Res. 1991, 96, 947.

58. Noziere, B. A.; Barnes, I.; Becker, K.-H.; J. Geophys. Res. 1999, 104, 23645.

59. Kamens, R. M.; Jaoui, M.; Environ. Sci. Technol. 2001, 35, 1394.

60. Larsen, B. R.; Di Bella, D.; Glasius, M.; Winterhalter, R.; Jensen, N. R.; Hjorth, J.; J. Atmos. Chem. 2001, 38, 231.

61. Lee, S.; Jang, M.; Kamens, R. M.; Atmos. Environ. 2004, 38, 2597. 
62. Aschmann, S.; Reissell, A.; Atkinson, R.; Arey, J.; J. Geophys. Res. 1998, 103, 25553.

63. Paulson, S. E.; Pandis, S. N.; Baltensperger, U.; Seinfeld, J. H.; Flagan, R. C.; Palen, E. J.; Allen, D. T.; Schaffner, C.; Giger, W.; Portmann, A.; J. Aerosol Sci. 1990, 21, S245.

64. Kotzias, D.; Fytianos, K.; Geiss, F.; Atmos. Environ. 1990, 24A, 2127.

65. Kavouras, I. G.; Mihalopoulos, N.; Stephanou, E. G.; Nature 1998, 395, 683.

66. Kavouras, I. G.; Mihalopoulos, N.; Stephanou, E. G.; Environ. Sci. Technol. 1999, 33, 1028.

67. Kavouras, I. G.; Mihalopoulos, N.; Stephanou, E. G.; Geophys. Res. Lett. 1999, 26, 55-59.
68. Zhang, X.; McMurry, P. H.; Environ. Sci. Technol. 1991, 25, 456.

69. Poster, D. L.; Hoff, R. M.; Baker, J. E.; Environ. Sci. Technol. 1995, 29, 1990.

70. Satsumabayashi, H.; Kurita, H.; Yokouchi, Y.; Ueda, H.; Atmos. Environ. 1990, 24A, 1443.

71. Calogirou, A.; Duane, M.; Kotzias, D.; Lahaniati, M.; Larsen, B. R.; Atmos. Environ. 1997, 31, 2741.

72. Arey, J.; Atkinson, R.; Aschmann, R.; Akimoto, S. M.; J. Geophys. Res. 1990, 95, 18539.

73. Odum, J. R.; Hoffmann, T.; Bowman, F.; Collins, D.; Flagan, R. C.; Seinfeld, J. H.; Environ. Sci. Technol. 1996, 30, 2580.

Received: May 26, 2004

Published on the web: August 3, 2005 